\title{
Nurmen täydennyskylvön hyvät käytänteet
}

\author{
Kirsi Mäkiniemi, Seppänen Timo, Kekkonen Piia
}

Savonia-ammattikorkeakoulu, Luonnonvara-ala, Haukisaarentie 2, 74130 Iisalmi

\section{TIIVISTELMÄ}

Rehunurmien hyvän satopotentiaalin säilyttäminen koko nurmikierron ajan on tärkeää, mikäli tilalla pyritään korkeisiin nurmen satotasoihin ja rehuomavaraisuuteen. Nurmen täydennyskylvö on yksi tärkeä keino satopotentiaalin säilyttämisessä. Keväällä 2018 Nurmet rahaksi -hankkeessa selvitettiin viljelijäkyselyn avulla nurmien täydennyskylvössä hyviksi havaittuja, toimivia käytänteitä ja täydennyskylvön onnistumisen ja siihen ryhtymisen reunaehtoja. Samalla selvitettiin myös sitä, milloin täydennyskylvö on tarpeen ja missä tilanteissa nurmen uusiminen onkin jo täydennyskylvöä järkevämpi vaihtoehto. Kyselyyn saatiin 16 kattavaa vastaussarjaa viljelijöiltä, joilla kaikilla oli kokemusta nurmien täydennyskylvöstä.

Vastausten perusteella hahmoteltiin kynnysarvot nurmen täydennyskylvölle ja uudistamiselle. Painavimpia syitä nurmien täydennyskylvöön olivat satotason nosto sekä nurmen tiheyden ylläpito ja nosto. Tavoitteena pidettiin yli $90 \%$ tiheää nurmea. Täydennyskylvön katsottiin olevan tarpeen ja tuottavan parhaan lopputuloksen silloin, kun tiheys on laskenut välille 70-80\%. Täydennyskylvöjen ennakointi ennen tiheyden merkittävää alenemista nousi esiin vastauksissa ja ennakoivat täydennyskylvöt koettiin erityisen tärkeiksi laidunnurmilla. Kokemusten perusteella yli 4 vuotta vanhojen nurmien tai alle $70 \%$ tiheiden nurmien elvyttäminen täydennyskylvämällä ei yleensä ole ollut järkevää, vaan näiden nurmien kohdalla tulee harkita uudistamista. Myöskään rikkakasvien pahasti valtaamilla tai juolavehnäisillä lohkoilla täydennyskylvöä ei pidetty toimivana keinona. Uudistaminen koettiin tarpeelliseksi myös silloin, kun lohkon kasvukunnossa on selkeitä puutteita.

Kokemusten mukaan täydennyskylvössä onnistuu, jos pellon ja kasvukauden olosuhteita osataan tulkita oikein: hyvä lopputulos vaatii viljelijän tai neuvojan jalkautumisen lohkolle, mieluiten aikaisin keväällä. Uusista teknologisista ratkaisuista esimerkiksi drone-kuvaus oli kiinnostava, mutta sen hyödyntämisestä nurmen havainnoinnissa oli ilmeisen vähän kokemusta. Onnistunut täydennyskylvö vaatii kostean maan, rikkatorjunnasta huolehtimisen sekä kunnollisen siemenen. Useimmat vastaajat pitivät kevättä parhaana täydennyskylvön ajankohtana.

Kyselyn vastausten perusteella koostettiin taulukko, jonka avulla rehunurmien täydennyskylvön tarvetta voi hahmotella omilla lohkoilla. Luokittelutekijöiksi valittiin nurmen tärkeimmät ominaisuudet, joita olivat nurmen ikä, tiheys, rikkakasvipitoisuus ja lajikoostumus sekä lohkon kuntotekijät ja olosuhteet. Mitä useamman luokittelutekijän osalta täydennyskylvön tarve on kohtalainen tai korkea, sitä tarpeellisempaa täydennyskylvö on. Taulukkoon koottiin myös kriteerit, joiden täyttyessä nurmen uudistamisen kipuraja ylittyy. Ohjeistuksessa huomioitiin myös se, että heikkokuntoisten nurmien kohdalla voidaan harkita nurmen iän jatkamista täydentämällä kasvustoa yksivuotiseksi pikanurmeksi.

Asiasanat: nurmi, säilörehu, laidun, heinä, täydennyskylvö, nurmen uudistaminen 


\section{Johdanto}

Rehunurmien hyvän satopotentiaalin säilyttäminen koko nurmikierron ajan on tärkeää, mikäli tilalla pyritään korkeisiin nurmen satotasoihin ja rehuomavaraisuuteen (Virkajärvi ym. 2015). Nurmen täydennyskylvö on yksi tärkeä keino satopotentiaalin säilyttämisessä. Kenttäkokeiden ja maatilakokeiden perusteella tähän kysymykseen ei ole pystytty saamaan vedenpitäviä vastauksia, koska eri vuosien olosuhdevaihtelut, kasvukauden sää ja lohkon ominaisuudet vaikuttavat epäilemättä merkittävästi lopputulokseen (esim. Kurki 2014, Hyrkäs ym. 2018). Perustetun nurmen hoidon - muun muassa täydennyskylvön ja rikkatorjunnan - sekä nurmikierron pituuden ja uusimisen välillä tasapainoilu on tuttua pohdintaa kaikille nurmia viljeleville. Jos täydennyskylvö ei vielä kuulu nurmitilan toimintatapoihin, joutuu viljelijä miettimään, milloin nurmen uudistamisen aika on tullut.

Keväällä 2018 Nurmet rahaksi -hankkeessa selvitettiin viljelijäkyselyn avulla nurmien täydennyskylvössä hyviksi havaittuja, toimivia käytänteitä ja täydennyskylvön onnistumisen ja siihen ryhtymisen reunaehtoja. Samalla selvitettiin myös sitä, milloin täydennyskylvö on tarpeen ja millä menetelmillä ja minä ajankohtana täydennyskylvötarve määritellään. Koska toisinaan nurmen uusiminen on täydennyskylvöä järkevämpi vaihtoehto, haluttiin selvittää myös sitä, millaisia kynnysarvoja uudistamiselle on ja milloin täydennyskylvö voisi olla hyvä vaihtoehto.

\section{Materiaalit ja menetelmät}

Kysely toteutettiin sähköisenä kyselytutkimuksena Webropol-palvelussa talvikaudella 2017-2018. Kysely painottui luokitteleviin ja asteikollisiin kysymyksiin, joiden tuloksia pystyttiin analysoimaan muun muassa frekvenssianalyysillä. Lisäksi aineistoa käsiteltiin joidenkin vastausten osalta niin, että täydennyskylvön onnistumista edistäviä tai haittaavia tekijöitä tutkittaessa laskettiin eri toimenpiteiden nettohyöty jättämällä neutraalit vastaukset huomiotta ja vähentämällä onnistumista edistäväksi mainituista vastausten summista onnistumista haittaavat vastaukset. Luokittelevien ja asteikollisten kysymysten lisäksi kyselyssä oli joitakin avoimia tekstikysymyksiä, joissa saatiin tarkentavia sanallisia vastauksia.

Kyselyyn saatiin 16 riittävän kattavaa vastaussarjaa. Näiden lisäksi saatiin muutamia vastaussarjoja tai yksittäisiä vastauksia, jotka jouduttiin hylkäämään ilmeisten virheiden tai "spämmäyksen" takia. Vastaajamäärä oli odotetusti pieni, koska kyselyyn vastaamisen edellytyksenä oli se, että vastaajalla on tietoa edustamansa maatilan nurmiviljelystä ja erityisesti nurmen täydennyskylvökäytännöistä. Vastaajat edustivat enimmäkseen maitotiloja (11 kpl), lisäksi vastanneissa oli mukana kaksi emolehmätilaa ja kolme kasvinviljely- tai hevostilaa. Tilat olivat yhtä luomutilaa lukuun ottamatta tavanomaisessa tuotannossa. Tilojen kokonaispinta-ala oli keskimäärin 78.38 ha, josta nurmikasveilla oli 63.44 ha (81\%). Tällä perusteella vaikutti siltä, että vastaajat edustivat keskimääräistä isompia tiloja, joilla nurmen merkitys on suuri. Neljällä vastaajista oli yli kymmenen vuoden kokemus nurmien täydennyskylvöstä ja keskimäärinkin täydennyskylvöä oli vastaajien edustamilla tiloilla harjoitettu yli 11 vuotta. Ensikosketus ja tietoa nurmen täydennyskylvöstä oli saatu useimmiten seminaarissa tai koulutuksessa (Kuva 1).

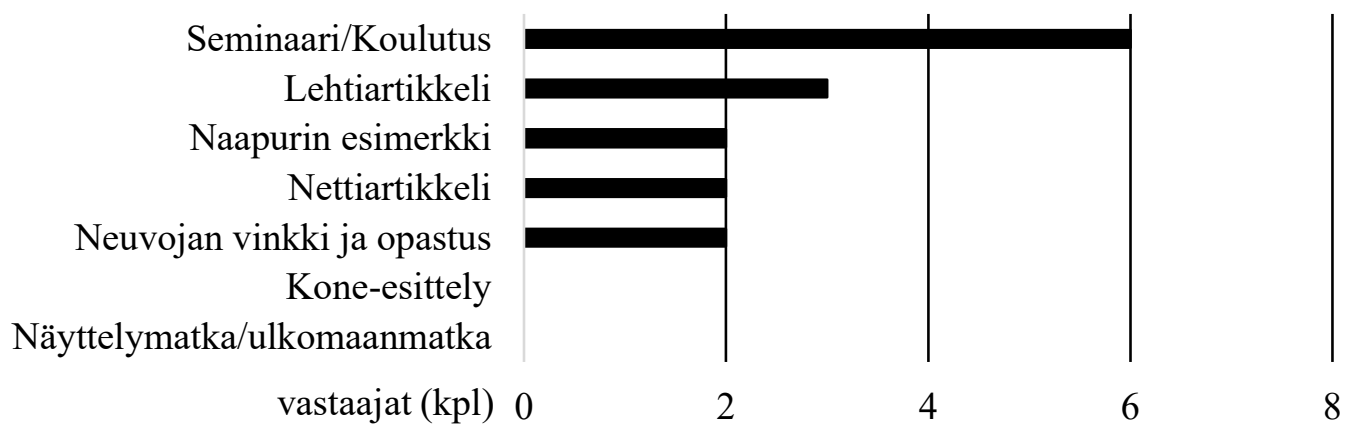

Kuva 1. Vastaajat olivat saaneet tietoa nurmen täydennyskylvöstä yleisimmin seminaarista, koulutuksesta tai lehtiartikkelista. 
Koska vastaajamäärä oli suhteellisen pieni, todettiin aineiston jakaminen tarpeettomaksi, joten eri tuotantosuuntien tai tuotantotapojen välisiä tilastollisia vertailuja ei tehty.

\section{Tulokset ja tulosten tarkastelu}

\section{Täydennyskylvön syyt ja tavoitteet}

Vastaajien mukaan painavimmat syyt nurmen täydennyskylvöön ryhtymiselle olivat satotason nosto sekä nurmen tiheyden ylläpito ja nosto (Kuva 2). Myös nurmisadon laadun parantamista ja nurmikierron pidentämistä pidettiin erittäin tärkeinä syinä täydennyskylvöön ryhtymisessä. Sen sijaan uusien kasvilajien lisäämistä nurmeen ei nähty kovin tärkeänä syynä.

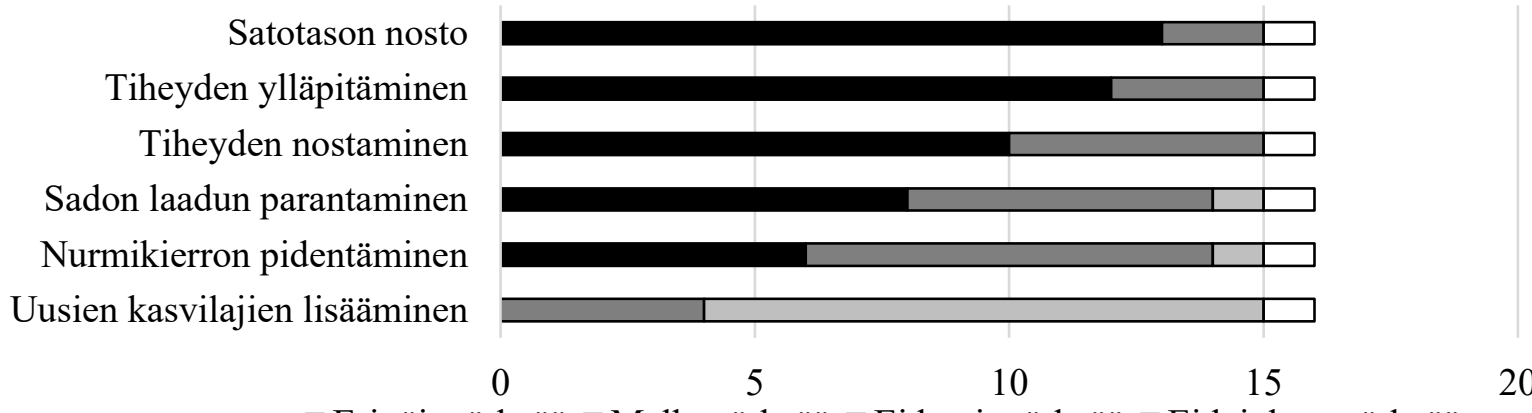

—Erittäin tärkeää $\square$ Melko tärkeää $\square$ Ei kovin tärkeää $\square$ Ei lainkaan tärkeää

Kuva 2. Satotaso ja nurmen tiheys ovat tärkeimmät syyt nurmen täydennyskylvölle.

\section{Nurmen täydennyskylvön ja uudistamisen kynnysarvot}

Vastausten perusteella hahmottuivat keskeisimmät kynnysarvot sille, milloin nurmilohko on tarpeen uusia kokonaan ja milloin täydennyskylvö on parempi vaihtoehto.

\section{Nurmen ikä}

Nurmen satotaso ja tiheys riippuvat usein nurmen iästä (Nissinen 2004, Virkajärvi ym. 2015). Vastaajien kokemusten perusteella nurmen uusiminen nousee täydennyskylvöä varteenotettavammaksi vaihtoehdoksi viimeistään yli 4 vuotta vanhojen nurmien kohdalla (Kuva 3). Sen sijaan täydennyskylvö nähtiin tarpeelliseksi erityisesti alle 3 vuotta vanhoilla nurmilla. Sanallisissa vastauksissa tuli esille se, että laitumilla uusimisväli on usein tarpeen pitää tiheämpänä kuin säilörehunurmilla tai vaihtoehtoisesti laitumia pitäisi täydennyskylvää herkemmin, ehkä jopa ennakoivasti.

Nurmi on yli 2 vuotta vanha
Nurmi on yli 3 vuotta vanha
Nurmi on yli 4 vuotta vanha 0

- Täydennyskylvö välttämätön $\square$ Täydennyskylvö melko tarpeeton $\mathbf{\Delta}$ Nurmi on uusittava

10

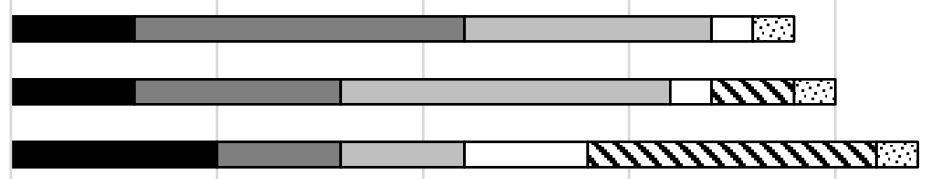

15 20 25

$\square$ Täydennyskylvö tarpeellinen $\square$ Täydennyskylvö täysin tarpeeton QEOS

Kuva 3. Alle 3 vuotta vanhoilla nurmilla täydennyskylvö on kokemusten mukaan toimiva ja yli 4 vuotta vanhoilla nurmilla nurmen uusiminen saattaa olla parempi valinta. ( $\mathrm{EOS}=$ ei osaa sanoa.)

\section{Nurmen tiheys}

Kovasatoisissa nurmissa nurmen tiheys on olennainen tekijä. Vastaajien kokemusten mukaan nurmea ei kannata uusia lohkoilla, joiden tiheys on yli $70 \%$ (Kuva 4). Täydennyskylvö kuitenkin katsottiin 
välttämättömäksi tai tarpeelliseksi erityisesti alle $80 \%$ tiheillä nurmilla ja vastaavasti tarpeettomaksi yli $90 \%$ tiheillä nurmilla. Näkemys on perusteltu, sillä esimerkiksi apilan täydennyskylvökokeissa on havaittu, että täydennyskylvöllä ei voida tihentää valmiiksi tiheitä nurmikasvustoja (Nykänen ym. 2004).

Kun nurmen tiheys on pudonnut $50-70 \%$ välille, kokemukset täydennyskylvön tai uusimisen paremmuudesta vaihtelivat ja varsin moni piti täydennyskylvöä välttämättömänä tai vähintään tarpeellisena toimenpiteenä, jos nurmea ei uusita. Jos nurmen tiheydestä on menetetty vähintään puolet, puoltaa nurmen uusiminen jo selkeästi paikkaansa.

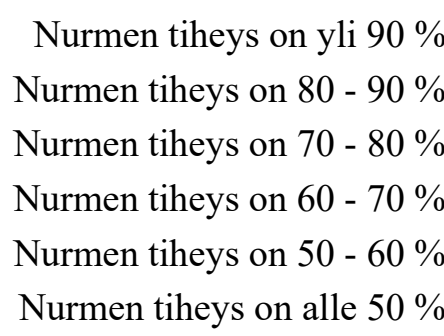

Nurmen tiheys on yli $90 \%$
Nurmen tiheys on $80-90 \%$
Nurmen tiheys on $70-80 \%$
Nurmen tiheys on $60-70 \%$
Nurmen tiheys on $50-60 \%$
Nurmen tiheys on alle $50 \%$

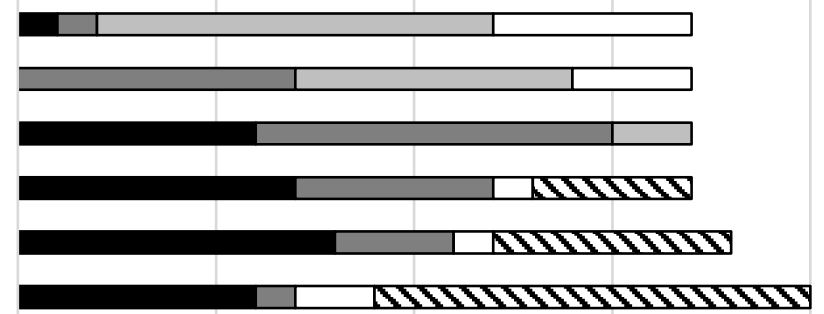

0

10

15

20

Täydennyskylvö välttämätön $\square$ Täydennyskylvö tarpeellinen $\square$ Täydennyskylvö melko tarpeeton $\square$ Täydennyskylvö täysin tarpeeton $\mathbf{\Delta N u r m i}$ on uusittava 든

Kuva 4. Yli $70 \%$ tiheät nurmet halutaan säilyttää ja niiden tiheyttä kannattaa parantaa täydennyskylvöllä. Tätä harvemmaksi päässeille nurmille kannattaa harkita nurmen uusimista. (EOS = ei osaa sanoa.)

\section{Nurmen rikkakasvipitoisuus ja ongelmarikkakasvit}

Nurmien rikkakasvipitoisuus ja rikkatorjunnan tarpeet määrittelevät myös nurmen uusimisen tai täydennyskylvön tarvetta. Nurmen uusimiskynnys ylittyy todennäköisimmin silloin, jos nurmessa on yli $20 \%$ rikkakasveja ja kasvusto on juolavehnäinen (Kuva 5). Juolavehnäongelman ja sen rikkatorjunnan kohdalla nurmen uusiminen onkin melko itsestään selvä vaihtoehto, koska nurmille sopivia valikoivia juolavehnän rikkatorjunta-aineita tai mekaanisia menetelmiä ei ole olemassa. Täydennyskylvö nähtiin tarpeellisimpana silloin, kun nurmessa on rikkakasveja $10-20 \%$, mutta alle $10 \%$ rikkapitoisilla nurmilla täydennyskylvö ei näytä puoltavan paikkaansa.

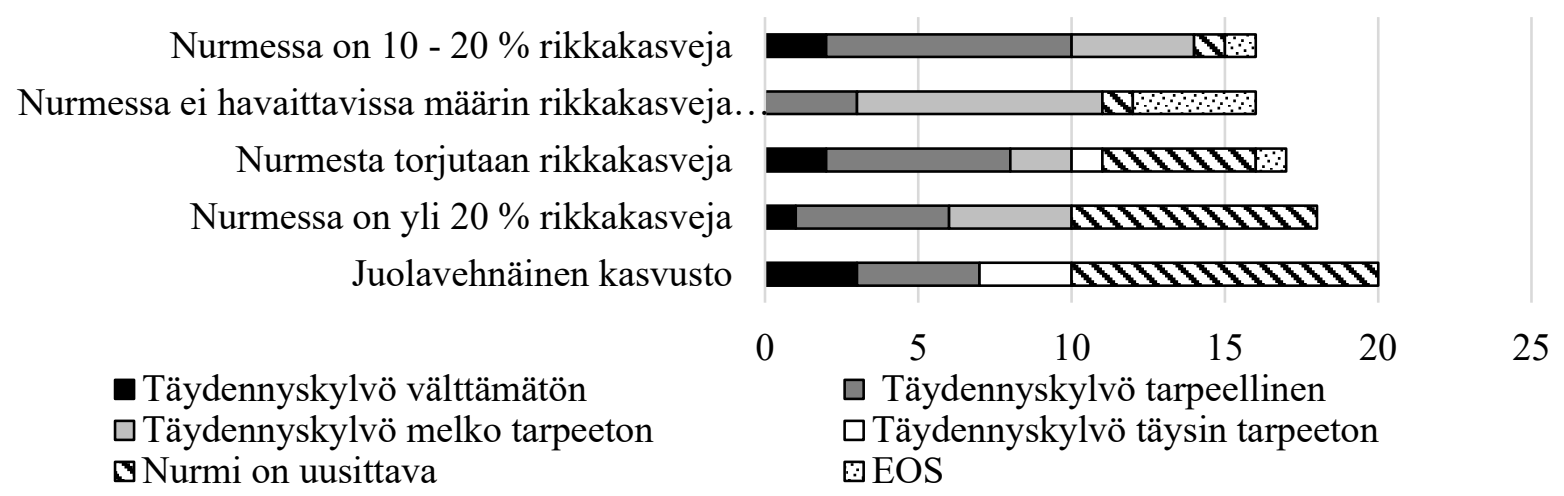

Kuva 5. Nurmen juolavehnäongelma ja yli $20 \%$ rikkakasvipitoisuus nostavat nurmen uusimisen tarvetta suhteessa täydennyskylvöön. Täydennyskylvöstä on apua alle $20 \%$ rikkapitoisen nurmen ylläpidossa. (EOS = ei osaa sanoa.) 


\section{Muut nurmen kuntoon vaikuttavat tekijät ja olosuhteet}

Nurmen uusimistarpeeseen vaikuttavat myös monet lohkokohtaiset tekijät ja olosuhteet. Täydennyskylvöä harjoittaneiden vastaajien kokemusten mukaan ongelmat pellon vesitaloudessa, pellon pinnan muotoilussa tai nurmen perustamisen onnistumisessa olivat syitä, jotka puoltavat nurmen uusimista (Kuva 6). Epäonnistumiset nurmen perustamisessa näyttäisivät kuitenkin olevan korjattavissa täydennyskylvöllä varsin monen vastaajan mielestä.

Täydennyskylvö nähtiin välttämättömänä tai tarpeellisena toimena silloin, kun nurmeen on päässyt syntymään talvituhoja tai kun nurmessa on pintavaurioiden aiheuttamaa aukkoisuutta. Siitä voi olla hyötyä myös silloin, jos pellon kasvukunto ei ole kunnossa esimerkiksi pH:n osalta. Tällöinhän täydennyskylvön laji- ja lajikevalinnalla voi pyrkiä tasapainottamaan tilannetta niin, että lohkolle saadaan sellainen nurmiseos, joka viihtyy lohkolla tai ainakin sietää paremmin olosuhteita.

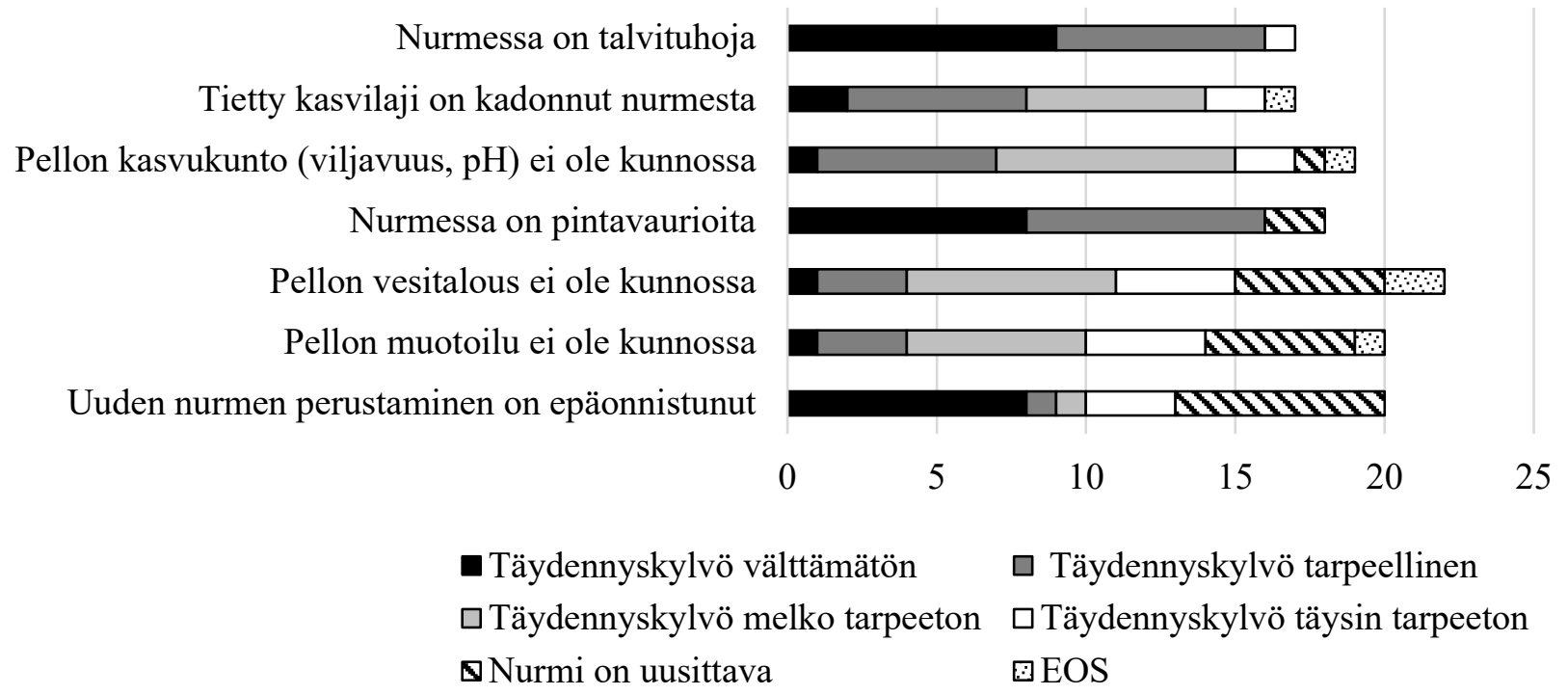

Kuva 6. Ongelmat pellon vesitaloudessa, muotoilussa ja nurmen perustamisessa lisäävät nurmen uusimispainetta. Täydennyskylvöllä voidaan korjata nurmen talvituhoja ja pintavaurioista johtuvaa aukkoisuutta. (EOS = ei osaa sanoa.)

\section{Täydennyskylvötarpeen arviointikeinot}

Vastaajien kokemusten perusteella joko aikainen kevät tai kasvuston kehittymisvaihe ovat parhaita ajankohtia, eikä sadonkorjuuhetki tai sen jälkeinen aika osoittautunut kasvustohavainnointeja paremmaksi (Kuva 7). Viljelijä on paras arvioinnin tekijä ja hänen tulee mieluiten jalkautua lohkolle tai tehdä havaintoja vaikkapa traktorin hytistä. Myös neuvojan havainnointiin luotettiin, kunhan hän jalkautuu lohkolle. Kasvustojen tarkkailun on aiemminkin havaittu johtavan siihen, että viljelijä havahtuu tekemään tiheyttä säilyttäviä toimenpiteitä ajoissa (Kurki 2014). Sen sijaan laidunnustulosten tai urakoitsijan havaintojen pohjalta täydennyskylvöpäätöksen tekeminen ei näyttänyt olevan yhtä varmaa.

Kyselyn vastausten perusteella GPS-paikannettu satokartoitus oli ehkä vähiten tunnettu uusi nurmien havainnointimenetelmä, koska siihen otti kantaa pienin osa vastaajista. Drone- tai muiden ilmakuvien kiinnostavuus näytti suuremmalta ja tässä tapauksessa vastaajat näkivät, että viljelijä itse on esimerkiksi neuvojaa parempi päättelemään nurmen täydennyskylvön tarvetta kuvien pohjalta. 


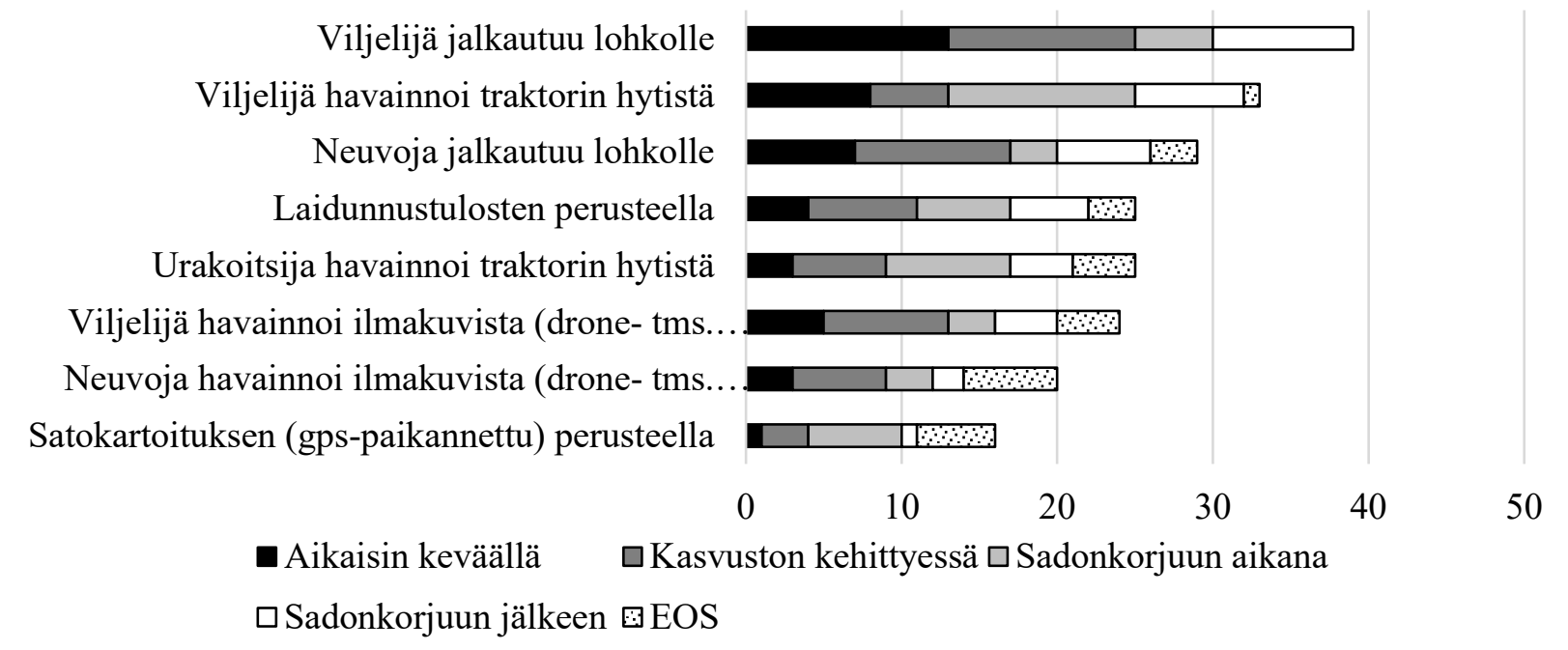

Kuva 7. Täydennyskylvöä harjoittavien viljelijöiden kokemukset eri havainnointimenetelmien sopivuudesta täydennyskylvötarpeen arvioinnissa. (EOS = ei osaa sanoa.)

\section{Täydennyskylvön onnistuminen ja sen havainnointi}

Täydennyskylvöä harjoittaneet viljelijät ovat yleensä myös havainnoineet täydennyskylvön onnistumista, joten kyselyssä selvitettiin onnistumisen reunaehtoja. Jotta parhaat menetelmät saatiin selville, laskettiin vastausten avulla onnistumisen nettohyötyä. Se muodostui siis sitä positiivisemmaksi, mitä useampi vastaaja oli nähnyt sen edistävän täydennyskylvön onnistumista ja mitä harvempi vastaaja näki sen vastaavasti haittaavan lopputulosta.

Kaikkein merkittävimmin nurmen täydennyskylvöä edistäviksi seikoiksi osoittautuivat kylväminen riittävän aikaisin keväällä silloin, kun pelto on kostea mutta kuitenkin kantava (Kuva 8). Viljelijöiden havainto tukee Kurjen (2010) kenttäkokeissa tekemiä havaintoja sekä hankkeiden täydennyskylvökokeiluissa saatuja tuloksia (Kurki 2014). Tämä korostui lisää sanallisissa vastauksissa, joissa moni painotti keväällisen itämiskosteuden ja riittävän aikaisen ajoituksen merkitystä. Myös rikkakasvien torjunnan yhdistäminen täydennyskylvöön vaikutti edistävän täydennyskylvössä onnistumista. Ennen varsinaista kylvöä tehtävistä päätöksistä kylvömäärän tarkka laskeminen ja säätö sekä räätälöidyn siemenseoksen hankinta olivat voimakkaasti täydennyskylvön onnistumista edistäviä tekijöitä.

Varsinaisista kylvömenetelmistä haraaminen, pneumaattinen eli ilma-avusteinen kylvö sekä jyrääminen oli koettu lopputulosta edistäviksi tekijöiksi. Myös Kurki (2014) on havainnut täydennyskylvön onnistuvan paremmin, kun siihen liittyy nurmiäestys, koska se parantaa siemenen maakontaktia ja varmistaa orastumisen. Myös lajikkeelle sopiva kylvösyvyys on vastaajien mielestä tärkeää. Sen sijaan muun muassa lietteenlevityksen nettohyöty jäi pieneksi: Kurjen (2014) peltokokeissa lietteen levitys jopa heikensi täydennyskylvön onnistumista.

Täydennyskylvön onnistumista eniten haittaavaksi tekijäksi osoittautui tilanne, jossa pelto on kuiva täydennyskylvön tekohetkellä. Muiksi onnistumista haittaaviksi tekijöiksi tai menetelmiksi osoittautuivat syksyllä tai kesällä nurmenkorjuiden jälkeen tehdyt täydennyskylvöt. Myös nämä havainnot ovat yhdenmukaisia Kurjen (2014) saamiin tuloksiin nähden. 
Täydennyskylvö aikaisin keväällä

Rikkakasvien torjunta

Pelto on kostea, mutta kantaa

Haraaminen

Tarkasti laskettu/säädetty kylvömäärä

Räätälöity nurmisiemen(seos)

Pneumaattinen (ilma-avusteinen) kylvö

Lajeille sopiva kylvösyvyys

Jyrääminen

Nurmensiemenen rivikylvö (maahan)

Yleisnurmisiemen(seos)

Nurmensiemenen hajakylvö (pintaan)

Lietteen levitys

Täydennyskylvö syksyllä

Täydennyskylvö 1. korjuun jälkeen

Täydennyskylvö 2. korjuun jälkeen

Pelto on kuiva

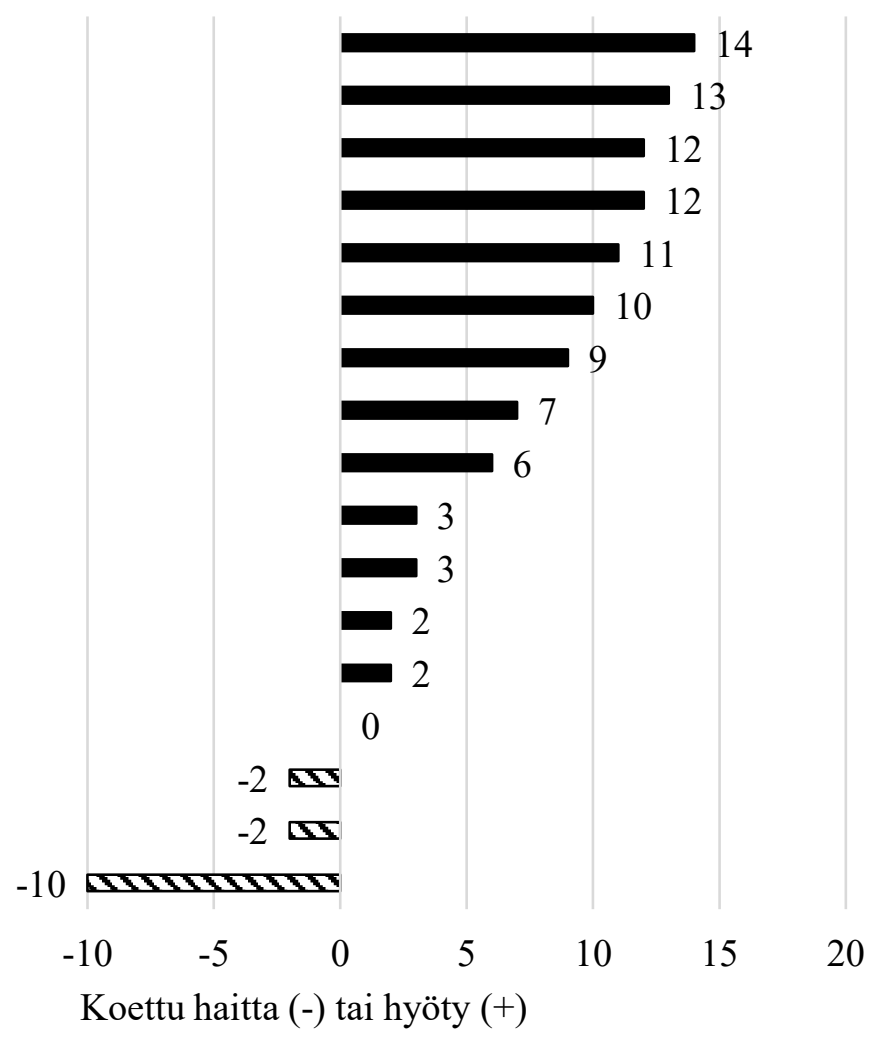

Koettu haitta (-) tai hyöty $(+)$

Kuva 8. Eri tekijöiden nettovaikutus (hyöty tai haitta) täydennyskylvön onnistumiselle

Täydennyskylvötuloksen havainnoinnissa viljelijät näyttivät luottavan eniten lohkolle jalkautumiseen (Kuva 9). Aikaisen kevään merkitys on tässä vaiheessa aivan ymmärrettävästi vähäisempi kuin varsinaisen täydennyskylvötarpeen arvioinnissa ja moni näkeekin, että sadonkorjuuhetki tai aika sen jälkeen on paras onnistumisten havainnointihetki. Myös uusi teknologia, kuten viljelijän itsensä arvioimat drone-kuvat nousevat tässä onnistumisten tarkasteluvaiheessa tärkeämmiksi kuin itse täydennyskylvöpäätöksen tekohetkellä.

Viljelijä jalkautuu lohkolle

Neuvoja jalkautuu lohkolle

Viljelijä havainnoi traktorin hytistä

Viljelijä havainnoi ilmakuvista (drone- tms..

Laidunnustulosten perusteella

Urakoitsija havainnoi traktorin hytistä

Neuvoja havainnoi ilmakuvista (drone- tms..

Satokartoituksen (gps-paikannettu) perusteella

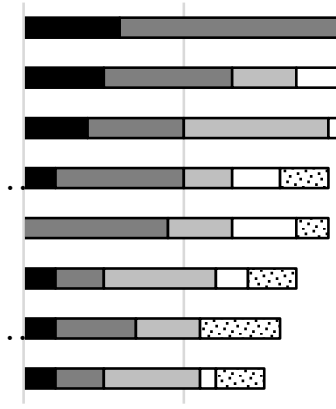

Aikaisin keväällä

$\begin{array}{lll}0 & 10 & 20\end{array}$

$20 \quad 30$

40

50

$\square$ Sadonkorjuun aikana

$\square$ Kasvuston kehittyessä

$\square$ Sadonkorjuun jälkeen 드요

Kuva 9. Eri havainnointimenetelmien sopivuus jo tehtyjen täydennyskylvöjen onnistumisen arviointiin. $(\mathrm{EOS}=\mathrm{ei}$ osaa sanoa.) 


\section{Johtopäätökset}

Kyselyyn saatujen vastausten perusteella täydennyskylvöpäätöksiä ja -toimenpiteitä tulee tehdä aikaisin keväällä, mieluiten jalkautumalla lohkolle joko itse tai neuvojan kanssa. Mitä pellolla pitäisi sitten osata havainnoida ja arvioida, ja miten lopulliseen päätökseen päästään järkisyitä käyttämällä? Täydennyskylvöä pitkään harjoittaneiden vastaajien kokemuksista erottui joitakin suhteellisen selkeitä tekijöitä tai ominaisuuksia, jotka näyttäisivät ratkaisevan sen, onko täydennyskylvölle tarvetta tai pitäisikö nurmi uudistaa kokonaan. Nurmen ikä on näistä yksi, mutta tämä on kuitenkin varsin tilakohtainen tekijä ja kannattaa muistaa, että joillakin tiloilla nimenomaan nurmikierron pidentäminen on se syy, miksi täydennyskylvöä halutaan tehdä. Siksi nurmen ikää voidaan pitää viitteellisenä tekijänä.

Nurmen tiheys ja rikkakasvipitoisuus olivat sen sijaan melko selkeitä tekijöitä, joiden pohjalta täydennyskylvö- tai uudistamispäätöksiä tehdään. Samoin nurmilohkon kuntotekijöistä ja olosuhteista löytyi ymmärrettäviä tilanteita, joissa nurmen uudistaminen jää oikeastaan ainoaksi järkeväksi keinoksi parantaa huonoa tilannetta - täydennyskylvö kun ei ratkaise perustavaa laatua olevia ongelmia, jos ongelmapaikalle sopivaa nurmilajia tai -lajiketta ei ole tai haluta käyttää.

Vastaajien kokemukset osoittavat, että yli 90\% tiheillä, lähes rikkakasvittomilla ja hyvässä kasvukunnossa olevilla lohkoilla täydennyskylvö on tarpeetonta. Näillä lohkoilla on toki syytä keskittyä säilyttämään hyvä tilanne. Kuten eräs vastaaja mainitsi, ennakointi on silti valttia ja kannattaakin olla tarkkana, milloin täydennyskylvö tulee näillä huippulohkoillakin kyseeseen. Täydennyskylvö koettiin välttämättömäksi tai vähintään tarpeelliseksi silloin, kun nurmen tiheys alkaa heikentyä ja rikkakasvit valtaavat nurmikasveilta vapautuvan kasvutilan. Tämä tilanne saattaa johtua esimerkiksi talvituhoista, koneiden tai eläinten aiheuttamista pintavaurioista tai siitä, että pellon $\mathrm{pH}$ tai muut olosuhteet eivät olekaan riittävän hyviä kylvetyille nurmikasvilajeille.

Vastauksista erottuneiden luokittelutekijöiden perusteella nurmilohkot voidaan jakaa hyviin, täydennyskylvettäviin, mahdollisesti uusittaviin ja ehdottomasti uusittaviin lohkoihin (Taulukko 1). Mitä pienempi tiheys tai mitä useampi muu negatiivinen luokittelutekijä täyttyy, sitä tarpeellisempi täydennyskylvö on. Mikäli lohkolla esiintyy lukuisia negatiivisia luokittelutekijöitä tai olosuhteita, alkaa täydennyskylvö olla käytännössä välttämätön nurmen korkean satotason ja laadun säilyttämiseksi. Kun näitä negatiivisia luokittelutekijöitä kertyy runsaasti, on ryhdyttävä harkitsemaan myös nurmen uudistamista. Toisaalta nurmi ei onneksi ole välttämättä tulevan kasvukauden osalta menetetty tapaus, jos sillä havaitaan keväällä useita negatiivisia ominaisuuksia: nurmen voi pelastaa yhdeksi lisävuodeksi rehuntuotantokuntoon täydennyskylvämällä nopeakasvuisia, yksivuotisia nurmilajeja.

Taulukko 1. Nurmilohkon täydennyskylvöön tai nurmen uudistamiseen johtavia luokitteluperusteita.

\begin{tabular}{|r|c|c|c|c|}
\cline { 2 - 5 } \multicolumn{1}{c|}{$\begin{array}{c}\text { Nurmen } \\
\text { ikä }\end{array}$} & $\begin{array}{c}\text { Nurmen } \\
\text { tiheys }\end{array}$ & $\begin{array}{c}\text { Nurmen rikkakasvipitoisuus } \\
\text { ja lajikoostumus }\end{array}$ & $\begin{array}{c}\text { Lohkon kuntotekijät } \\
\text { ja olosuhteet }\end{array}$ \\
\hline ei tarvetta toimenpiteille & & yli $90 \%$ & rikkoja alle $10 \%$ & ei ongelmia \\
\hline $\begin{array}{r}\text { Harkitse } \\
\text { täydennyskylvön } \\
\text { tarvetta }\end{array}$ & 2 & $80-90 \%$ & rikkoja $10-20 \%$ & talvituhoja \\
\cline { 2 - 5 } & 4 & $60-80 \%$ & kylvetty laji hävinnyt & pintavaurioita \\
\hline $\begin{array}{r}\text { Harkitse nurmen } \\
\text { uudistamista tai } \\
\text { tee huolellinen } \\
\text { täydennyskylvö }\end{array}$ & 3 & $60-70 \%$ & kylvetty laji hävinnyt & $\begin{array}{c}\text { nurmen perustaminen } \\
\text { epäonnistunut }\end{array}$ \\
\cline { 2 - 5 } & 5 & $50-60 \%$ & rikkoja yli $20 \%$ & ongelmat vesitaloudessa \\
\hline $\begin{array}{r}\text { Uudista nurmi tai kylvä } \\
\text { yksivuotinen täydennys }\end{array}$ & & alle $50 \%$ & $\begin{array}{c}\text { jos useita yllämainittuja } \\
\text { ongelmia }\end{array}$ & $\begin{array}{c}\text { jos useita yllämainittuja } \\
\text { ongelmat pinnan } \\
\text { ongelmia }\end{array}$ \\
\hline
\end{tabular}




\section{Kirjallisuus}

Hyrkäs, M., Kykkänen, S., Virkajärvi, P., Kanninen, J., Laakso, J. \& Korhonen, P. 2018. Nurmen täydennyskylvön vaikutus satoon aukkoisessa kasvustossa. Suomen Maataloustieteellisen Seuran Tiedote 35. https://doi.org/10.33354/smst.73217

Kurki, P. 2010. Täydennyskylvö. Teoksessa: Peltonen, S. ym. (toim.). Nurmirehujen tuotanto ja käyttö. Tieto Tuottamaan 132. ProAgria Keskusten Liitto. s. 46-48.

Kurki, P. 2014. Satovaihtelu taltutetaan tarkkailulla ja täydennyskylvöillä. Maaseudun Tiede 1:14.

Nissinen, O. 2004. Nuori nurmi tuottaa eniten. Koetoiminta ja käytäntö 61:13.

Nykänen, A., Jauhiainen, L., Nykänen-Kurki P., Avikainen, H. \& Leinonen, P. 2004. Apilan kylvön jaksottamisesta tuloksia. Koetoiminta ja käytäntö 4:6. 